\title{
Nutritional content of bat-consumed fruits in a forest fragment in Southern Brazil
}

\author{
C. B. Batista ${ }^{a}$, N. R. Reis ${ }^{a}$ and M. I. Rezende ${ }^{b}$ \\ aPrograma de Pós-graduação em Ciências Biológicas, Laboratório de Mastoecologia, Centro de Ciências Biológicas, \\ Universidade Estadual de Londrina - UEL, Rodovia Celso Garcia Cid, Pr 445, Km 380, Campus Universitário, \\ CP 10.011, CEP 86057-970, Londrina, PR, Brazil

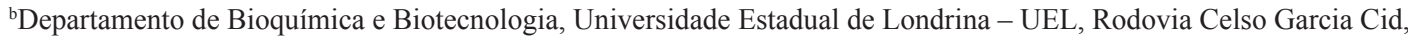 \\ Pr 445, Km 380, Campus Universitário, CP 10.011, CEP 86057-970, Londrina, PR, Brazil \\ *e-mail: blefaricarol@gmail.com
}

Received: July 1, 2015 - Accepted: January 31, 2016 - Distributed: May 31, 2017

(With 2 figures)

\begin{abstract}
The State Park Mata dos Godoy has 42 identified bat species, among which 21 are frugivorous and belong to the Phyllostomidae family. Current study investigated the concentrations of carbohydrate, lipid and protein in fruits consumed by Artibeus lituratus, Carollia perspicillata and Sturnira lilium to understand their potential differentiated food preferences. The Sampling effort it was from April/2013 to March/2014. Animals captured in mist nets were identified in the field and maintained in cotton bags for 30 minutes to defecate. The diet was inferred from fecal samples analyzed in the laboratory, the fruits whose seeds were found in the feces had the determinations of the nutrients accomplished by centesimal composition method. Kruskal-Wallis test and Dunn's multiple comparison method verified the most abundant nutrients for each species of bat. Whereas Carollia perspicillata and Sturnira lilium feeds mainly in food with carbohydrates that provide them with more energy, the diet of Artibeus lituratus is richer in carbohydrates and lipids. Only fruits considered scarcely represent a complete nutrition for the three bat species, however, the complementarity with other food items such as leaves, pollen, and insects, can provide a complete nutrient diet for these animals.
\end{abstract}

Keywords: Chiroptera, frugivore diet, nutrition value.

\section{Conteúdo nutricional de frutos consumidos por morcegos em um fragmento florestal do sul do Brasil}

\section{Resumo}

O Parque Estadual Mata dos Godoy possui 42 espécies descritas de morcegos, dentre as quais 21 são frugívoras e representadas pela família Phyllostomidae. O objetivo foi verificar qual a concentração de carboidratos, lipídeos e proteínas nos frutos consumidos por Artibeus lituratus, Carollia perspicillata, e Sturnira lilium para entender suas preferências alimentares diferenciadas. A amostragem se deu de abril/2013 a março/2014. Os animais capturados em redes de neblina foram identificados em campo e alocados em sacos de algodão por 30 minutos para defecarem. A dieta foi inferida a partir de amostras fecais analisadas em laboratório, os frutos cujas sementes foram encontradas nas fezes tiveram as determinações dos nutrientes realizadas por composição centesimal. Para verificar qual nutriente mais abundante na dieta foi realizado, para cada espécie de morcego, o teste de Kruskal Wallis seguido do método de comparações múltiplas de Dunn. Enquanto que Carollia perspicillata e Sturnira lilium alimentam-se de frutos que provém energia a partir de mais carboidratos, a dieta de Artibeus lituratus é rica não apenas em carboidratos como também lipídeos. Apenas os frutos analisados não representam uma nutrição completa para as três espécies de morcegos, no entanto, a complementariedade com outros itens alimentares como folhas, pólen e insetos, pode fornecer uma dieta completa em nutrientes para estes animais.

Palavras-chave: Chiroptera, dieta frugívora, valor nutritivo.

\section{Introduction}

Animals are strictly dependent on nutrients, such as proteins, carbohydrates and lipids, for growth and reproduction. The energy required for metabolism is obtained from these nutrients and can be used as soon as they are acquired or stored in body tissues as energy reserve to be used when needed (White, 1993; Bentley, 
1998; Genuth, 1998; Ricklefs, 2010). The Energy comes from plant species whose energy value depends on the quality and quantity of its energy, or rather, the amount of energy that is assimilated of the ingested food (Neuweiler, 2000; Schmidt-Nielsen, 2011).

Proteins, carbohydrates and lipids are the main organic compounds in the diet of animals. When oxidized, they produce almost all the chemical energy for metabolism or energy-releasing reactions (Schmidt-Nielsen, 2011). Although the three nutrients release energy when oxidized, the amount per gram of calorie varies. Fat oxidation releases $37 \mathrm{Kj} / \mathrm{g}$ when compared to $16 \mathrm{Kj} / \mathrm{g}$ from carbohydrates and $18 \mathrm{Kj} / \mathrm{g}$ from proteins (Gleeson, 2005). However, since carbohydrates are metabolized faster (Smith et al., 1988), this nutrient is the main source of energy for animals (Dierenfeld and Seyjaget, 2000). The Basal Metabolism Rate (BMR), which represents, the minimum amount of energy required for the organism's activities (Odum, 2004), varies individually and depend on of different food strategies to meet distinct nutritional requirements (Bozinovic et al., 2007). Consequently, nutrition analyses focusing on the amounts of carbohydrates, lipids and proteins in zoochoric foods are relevant to assess diet contents and for cognize the amount of these nutrients to which animals have access when they consume certain fruits.

Studies on the selection of fruits by bats report that these mammals can differ on their preferences for specific plant genera. Carollia perspicillata (Linnaeus, 1758), Artibeus lituratus (Olfers, 1818) and Sturnira lilium (É. Geoffroy, 1810) (Reis et al., 2012) are the most common phyllostomids in the State Park Mata dos Godoy. Artibeus lituratus has a preference for fruits of the genera Ficus and Cecropia (Fleming, 1986, Vleut et al., 2015), although it also widely consumes Syagrus and Terminalia (Muller and Reis, 1992; Passos and Passamani, 2003; Mello et al., 2011); C. perspicillata feeds mainly on Piper and sometimes Solanum (Passos et al., 2003; Aguiar and Marinho Filho, 2007); and S. lilium prefers Solanum (Muller and Reis, 1992; Mello et al., 2008; Muylaert et al., 2014). Although these preferences are well known, few studies have investigated the nutrition amounts that frequently consumed fruits afford to the animals.

Wendeln et al. (2000) evaluated the nutrient composition of 14 species of Ficus in Panama, often selected by many frugivorous, including bats, and concluded that the genus could provide carbohydrates, lipids, proteins and minerals in the necessary amounts for sustain frugivorous only when combined different species within this genus. Lima and Reis (2004) calculated the nutrition composition of five Piper species consumed by $C$. perspicillata and reported higher carbohydrate when compared to lipid and protein values. Similar quantities were reported by Oliveira et al. (2012), who determined the nutrient composition, including water, sugars and proteins, of seven genera and nine species of fruits consumed by bats of the Brazilian Pantanal.

Since we assume that food preferences may exist due to distinct amounts of energy in fruits (Schaefer et al., 2003), we assessed the concentration of carbohydrates, lipids and proteins in fruits consumed by C. perspicillata, A. lituratus and S. lilium in the State Park Mata dos Godoy. We aimed to evaluate the nutrients provided by fruits frequently consumed by each species and to understand their potential differentiated food preferences.

\section{Materials and Methods}

\subsection{Study area}

Our research was conducted in the State Park

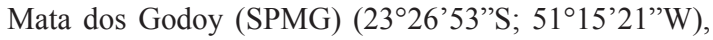
in the municipality of Londrina PR, southern Brazil, which comprises a 680-ha fragment of primary Atlantic Rainforest, surrounded by agricultural areas and linked to other fragments, forming approximately a 2,800-ha mosaic area (Vicente, 2006). The SPMG vegetation may be classified as sub-mountain semi-deciduous seasonal forest with great richness in the Lauraceae, Leguminosae, Myrtaceae, Euphorbiaceae, Flacourtiaceae and Meliaceae families (Silveira, 2006). A great abundance of Piperaceae, Moraceae, Urticaceae and Solanaceae may be found in the understorey, coupled to Arecaceae on the canopy, frequently used by frugivorous animals, including bats (Rossetto and Vieira, 2013).

Following Koppen's classification (Koppen, 1948), the climate is mesothermal humid subtropical (Cfa). Mean yearly temperature is around $21^{\circ} \mathrm{C}$; annual rainfall is $1,450 \mathrm{~mm}$; relative air moisture lies at approximately $75 \%$ (Vicente, 2006).

\subsection{Capture of the bats}

Mist nets (9 x $3 \mathrm{~m}, 32 \mathrm{~mm}$ mesh) were distributed randomly along two pathways in the State Park Mata dos Godoy, between April 2013 and March 2014, four times a month. They were set at sunset and closed after 12 hours, with a sampling effort of $62.208 \mathrm{~m}^{2} . \mathrm{h}$ (Straube and Bianconi, 2002). The captured animals were identified in the field, following Vizotto and Taddei (1973), Gardner (2008) and Reis et al. (1993, 2013). Individuals of A. lituratus, C. perspicillata and S. lilium were placed in cotton bags for 30 minutes to defecate and then released.

\subsection{Fecal analyses and fruit collection}

The diet of the three phyllostomid bats was analyzed from the feces samples, which were conditioned in plastic envelopes, tagged and analyzed in the laboratory, by stereoscopic microscope. The seeds in the faeces were washed and identified up to species level by comparing them to a previously prepared data bank with fruits collected from SPMG, and to the data bank of the Herbarium of the State University of Londrina. We collected also forty grams of mature fruits from at least three specimens from each plant species in the diet recorded in our field samples. In the case of A. lituratus, nutritional analyses were extended to species which, although not found in the fecal samples, are available in the SPMG and are known to be frequently consumed by the bat, namely, Syagrus romanzoffiana Cham., Terminalia catappa L., Cecropia glaziovii Snethl. and Cecropia pachystachya Trécul (Muller and Reis, 1992; 
Passos and Passamani, 2003; Mello et al., 2011). Such a choice was taken since $A$. lituratus was captured during the last two months of sampling (February and March 2014) when the mist-nets were set near a forest clearing close to the fig trees. This fact may have affected results. Further, although the bats were kept in cotton sacks for $30 \mathrm{~min}$, most did not defecate. In spite of the fact that throughout the year the fruits of Ficus, Cecropia, Terminalia and Syagrus were available within the study area, we do not know why $A$. lituratus was not captured during the entire sampling period, however Santos (2014) also reported low capture of this species in the same area.

\subsection{Analyses of lipid, carbohydrate and protein amounts}

Carbohydrates, lipids and proteins was determined on two samples from each vegetal species to obtain the average of these samples, each weighing $20 \mathrm{~g}$, by Centesimal Composition method, following analytic norms of the Adolfo Lutz Institute (IAL, 2005). Analyses were performed at the Department of Biochemistry and at the Department of Food Biotechnology and Technology of the State University of Londrina (UEL).

\subsection{Data analyses}

Frequency of occurrence of the seeds in the faeces was calculated to identify the most ingested food item (plant species) for the three bat species. Total fecal samples of each bat specie represented $100 \%$ and the number of fecal samples with each vegetal species was employed to calculate the frequency of occurrence (\%) of the vegetal species in the diet.
Differences on fruit carbohydrates, lipids and protein amount were tested by the Kruskal-Wallis test, since they were not normally distributed, and by Dunn's a posteriori test, so that plant species consumed by each animal represented each one of the three nutrients. Analyses were undertaken with Bioestat 5.0 (Ayres et al., 2007) at 0.016 significance level, after Bonferroni correction, due to multiple analyses.

\section{Results}

270 specimens were captured: 151 were identified as C. perspicillata (55.9\%); 64 as A. lituratus $(23.7 \%)$ and 55 as S. lilium (20.4\%), respectively with 71, 6 and 21 fecal samples. Ten plant species were detected on faeces, namely, Piper aduncum, Piper crassinervium, Piper glabratum, Piper gaudichaudianum, Piper umbellatum, Ficus insipida, Ficus sp, Solanum caavurana, Solanum granulosoleprosum and Solanum sisymbrifollium. Artibeus lituratus consumed only the genus Ficus, with Ficus insipida in $67 \%$ of the fecal samples for this species. C. perspicillata consumed Piper and Solanum fruits, with Piper aduncum as the most consumed fruit (59\%). S. lilium ingested Piper, Solanum and Ficus, with Solanum granulosoleprosum as the most consumed (38\%) (Figure 1).

Analysis of the chemical composition showed high carbohydrate amounts for fruits of the genera Piper (except Piper glabratum), Terminalia, Solanum (except Solanum sisymbrifollium) and Syagrus. Fruits of the genera Cecropia, Ficus, and the species Piper glabratum and Solanum sisymbrifollium have higher lipid amounts. Proteins were detected in small amounts in all species (Table 1).

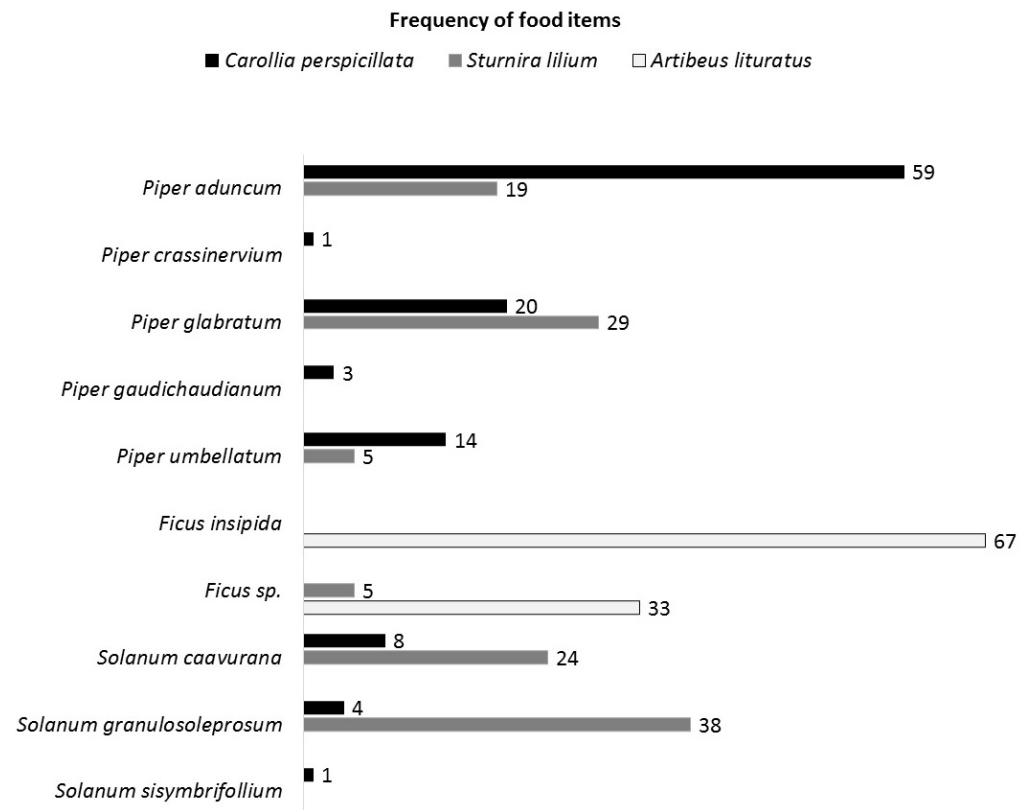

Figure 1. Frequency of occurrence of fruit consumed by Artibeus lituratus, Carollia perspicillata and Sturnira lilium in the State Park Mata dos Godoy, northern region of the state of Paraná, Brazil. Data from the literature on A. lituratus were not included in the figure. 
The Kruskal-Wallis test and Dunn's Method demonstrated that $A$. lituratus significantly consumed fruits with more carbohydrates and lipids, taking into consideration not only the amount of nutrients of the fruit (F. insipida) found in the faeces but also frequently consumed fruits reported in the literature, whereas fruits consumed by C. perspicillata and S. lilium provided mainly carbohydrates (Table 2, Figure 2).

\section{Discussion}

When analyzed as a set of fruits consumed by C. perspicillata, $S$. lilium e $A$. lituratus, median values reveal greater amounts of carbohydrates and fewer protein amounts. This fact corroborates results in other studies that determined the nutrient amounts of fruits in the diet of frugivorous bats (Dumont et al., 2004; Lima and Reis, 2004; Oliveira et al., 2012). In the case of A. lituratus, analyses of fruits whose seeds were not found in the faeces were included, although they were commonly ingested by the species, according to the literature (Muller and Reis, 1992; Passos and Passamani, 2003; Mello et al., 2011), and which occur in the SPMG. Only the fruits consumed by this species have the same amount of lipids as that of carbohydrates.

Since food for the bat species in the SPMG is abundant, individuals may be highly selective and they may be limiting their diet to the most convenient food (Delorme and Thomas, 1999), which would be the item with the greatest number of calories or that provide more energy, either as carbohydrates or lipids, and protein (Pianka, 1982).

The bat-consumed plants can be divided into two distinct groups (Wendeln et al., 2000; Saldaña-Vázquez and Schondube, 2013): those that are poor in nutrients, providing 36 to $50 \%$ carbohydrates, but small amounts of lipids and proteins (1-5\%); and those that are rich in nutrients, with higher amounts of carbohydrates, lipids

Table 1. Mean quantity $(\mathrm{n}=2)$ in percentage of carbohydrates, lipids and proteins in fruits of vegetal species consumed by Artibeus lituratus, Carollia perspicillata and Sturnira lilium, in the State Park Mata dos Godoy, northern region of the state of Paraná, Brazil. Each line does not sum to $100 \%$ because the amounts of water and ashs were removed.

\begin{tabular}{lccc}
\hline \multicolumn{1}{c}{ Vegetal species } & Proteins (\%) & Lipids (\%) & Carbohydrates (\%) \\
\hline Piper aduncum L. & 7.83 & 11.27 & 58.42 \\
Piper crassinervium Kunth & 3.82 & 1.43 & 63.69 \\
Piper glabratum Kunth & 5.71 & 38.41 & 27.53 \\
Piper gaudichaudianum Kunth & 3.6 & 1.45 & 47 \\
Piper umbellatum L. & 4.47 & 1.68 & 57.06 \\
* Cecropia glaziovii Snethl. & 4.85 & 43.97 & 19.36 \\
* Cecropia pachystachya Trécul & 8.41 & 34.525 & 24.96 \\
*Terminalia catappa L. & 1.51 & 30.33 & 53.21 \\
Ficus insipida Willd. & 1.4 & 45.78 & 29.44 \\
Solanum caavurana Vell. & 4.25 & 1.55 & 56.69 \\
Solanum granulosoleprosum Dunal & 3.55 & 1.64 & 56.57 \\
Solanum sisymbrifollium Lam. & 5.06 & 37.24 & 26.43 \\
* Syagrus romanzoffiana Cham. & 1.49 & 7.95 & 65.86 \\
\hline
\end{tabular}

*Analyses of fruits frequently consumed by A. lituratus, according to the literature.

Table 2. Number of consumed vegetal species used as replica for the Kruskal-Wallis analysis of variance, medians, $\mathrm{H}$ values and $\mathrm{p}$-values from test and results of comparative test by Dunn's method.

\begin{tabular}{|c|c|c|c|c|c|}
\hline & $\begin{array}{c}\text { Number of } \\
\text { vegetal species } \\
\text { consumed }\end{array}$ & Nutriens & $\begin{array}{l}\text { Median for } \\
\text { nutrient } \\
\text { amount } \\
(\%) \\
\end{array}$ & $\begin{array}{c}\text { Kruskal- } \\
\text { Wallis'H and } \\
\text { p-value }\end{array}$ & $\begin{array}{l}\text { Comparison by } \\
\text { Dunn's method } \\
\text { and p-value }\end{array}$ \\
\hline \multirow{3}{*}{ Artibeus lituratus $N=$} & \multirow{3}{*}{5} & Proteins & 1.51 & \multirow{3}{*}{$\begin{array}{l}H=8.66 \\
(0.013)\end{array}$} & $\mathrm{C}$ and $\mathrm{L}-\mathrm{ns}$ \\
\hline & & Carbohydrates & 29.44 & & $\mathrm{C}$ and $\mathrm{P}-\mathrm{p}<0.05$ \\
\hline & & Lipids & 34.52 & & $\mathrm{~L}$ and $\mathrm{P}-\mathrm{p}<0.05$ \\
\hline \multirow{3}{*}{ Carollia perspicillata $N=$} & \multirow{3}{*}{8} & Proteins & 4.36 & \multirow{3}{*}{$\begin{array}{c}H=13.68 \\
(0.001)\end{array}$} & $\mathrm{C}$ and $\mathrm{L}-\mathrm{p}<0.05$ \\
\hline & & Carbohydrates & 56.63 & & $\mathrm{C}$ and $\mathrm{P}-\mathrm{p}<0.05$ \\
\hline & & Lipids & 1.65 & & $\mathrm{~L}$ and $\mathrm{P}-\mathrm{ns}$ \\
\hline \multirow{3}{*}{ Sturnira lilium $N=$} & \multirow{3}{*}{5} & Proteins & 4.47 & \multirow{3}{*}{$\begin{array}{l}H=8.72 \\
(0.012)\end{array}$} & $\mathrm{C}$ and $\mathrm{L}-\mathrm{p}<0.05$ \\
\hline & & Carbohydrates & 56.69 & & $\mathrm{C}$ and $\mathrm{P}-\mathrm{p}<0.05$ \\
\hline & & Lipids & 1.67 & & $\mathrm{~L}$ and $\mathrm{P}-\mathrm{ns}$ \\
\hline
\end{tabular}

C-Carbohydrates; L - Lipids; P- Proteins; ns - not significant. Significance level at 0.016 for Kruskal-Wallis test, with Bonferroni correction. 
and proteins (5-7\%) (Fleming, 1986; Wendeln et al., 2000; Saldaña-Vázquez and Schondube, 2013). The above studies fail to provide percentages of lipids which would show low or high nutrient amounts.

Carbohydrates - Fruits ingested by A. lituratus, S. lilium and $C$. perspicillata provide energy mainly as carbohydrates which are the greatest source of energy and the substrate for many synthesis pathways. They are ready for energy demands or may be stored in the liver and muscles as glycogen for the maintenance of glucose when the animals are submitted to short periods of fasting (12-48 hours; Pinheiro et al., 2006).
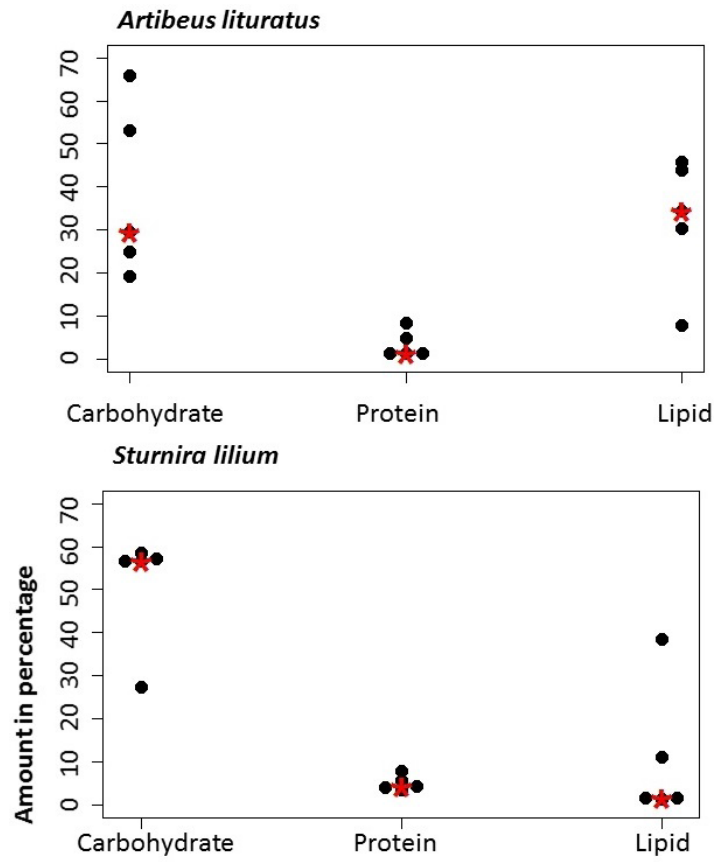

Carollia perspicillata

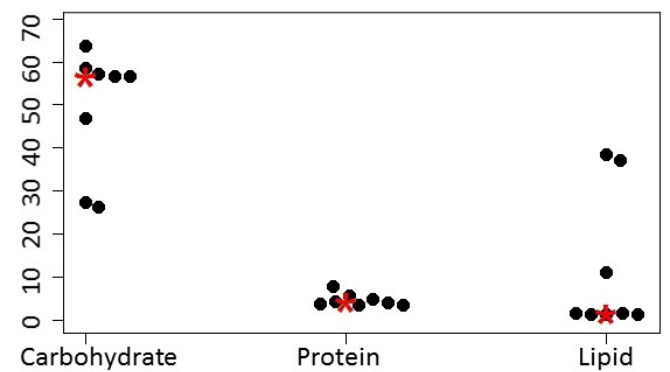

Figure 2. Axis x represents carbohydrate, lipid and protein percentages of each fruit analyzed for Artibeus lituratus, Carollia perspicillata and Sturnira lilium in the State Park Mata dos Godoy, northern region of the state of Paraná, Brazil. Each dot represents a type of fruit. In the case of $A$. lituratus, there are five dots for each nutrient, representing five fruits analyzed for the species; in the case of S. lilium and $C$. perspicillata, there are eight dots since eight fruits were analyzed for each bat. Star indicates median for carbohydrates, lipids and proteins in the fruits.
Bats supply their high energy demands through their ability in executing a fast combustion of recently ingested carbohydrates. In fact, they must burn diet nutrients instantly to sustain immediate energy and high requirements for flight (Voigt et al., 2010).

Lipids - The amounts of lipids in the fruits analyzed were high only for A. lituratus, whereas lipids were the smallest part of the nutrient composition for C. perspicillata and $S$. lilium. However, the first and second most consumed item, respectively Piper aduncum (Vleut et al., 2015, also found P. aduncum as the item most sought by $C$. perspicillata) and Piper glabratum, provided greater amounts of lipids when compared to those of other fruits also consumed by the species. The same occurred with S. lilium with regard to $P$. glabratum as the second most required item.

Lipids rather than carbohydrates are more efficient in the storage of energy, due to the fact that adipose cells contain smaller amounts of water when compared to the great quantity of water required to store carbohydrates (Gleeson, 2005). Lipid reserves have an important role in the energy demands of flight and in case of food scarcity, or during daytime when bats do not forage. Fat is the only fuel which, when stored, warrants great energy reserves to meet the body needs during long fasting periods (Gleeson, 2005).

Proteins - All fruits consumed by the three bat species have low amounts of proteins when compared to other nutrients. However, A. lituratus includes fruits of Cecropia pachystachya in its diet and C. perspicillata and S. lilium feed on P. aduncum and P. glabratum, among other items. The fruits of these three vegetal species have high amounts of protein in nutrient-rich plants.

These nutrients are not the most efficient to acquire energy since there is no protein reserve that may be discriminated without the loss of functional capacity (Gleeson, 2005). In fact, all protein exists for the execution of vital functions in animal organism, such as the transport of other objects, metabolic reactions, muscular contractions, structuring and repair of tissues (Emery, 2012).

While taking into consideration the nutrient amounts of the fruits under analysis, no single fruit provides carbohydrates, lipids and proteins in similar quantities. However, the diversity of fruit ingested by the three bat species may represent a rich energy diet. It is common knowledge that A. lituratus, $C$. perspicillata and $S$. lilium supplement their diet with other items, such as leaves, pollen and insects, which have not been analyzed in current paper (Sazima, 1976; Bernard, 1997; Mikich, 2002; Reis et al., 2013). Coupled to fruits, they may provide calories and structure quality required for the maintenance of the organism. Thus, a diet based only on analyzed fruits does not provide all the nutrients needed for growth, reproduction and metabolism of three species 
of bats. For surely know if these animals ingest enough nutrients to maintain the body, should be considered an analysis of the all foods included in the diet, such as seeds, leaves, pollen and insects.

\section{References}

AGUIAR, L.M.S. and MARINHO-FILHO, J., 2007. Bat frugivory in a remnant of Southeastern Brazilian Atlantic forest. Acta Chiropterologica, vol. 9, no. 1, pp. 251-260. http://dx.doi. org/10.3161/1733-5329(2007)9[251:BFIARO]2.0.CO;2.

AYRES, M., AYRES JÚNIOR, M., AYRES, D.L. and SANTOS, A.A., 2007. Bioestat - aplicações estatísticas nas áreas das ciências biomédicas. Belém: Ong mamiraua.

BENTLEY, P.J., 1998. Hormones and nutrition. In: P.J. Bentley, ed. Comparative vertebrate endocrinology. New York: Cambridge University Press, pp. 223-268.

BERNARD, E., 1997. Folivory in Artibeus concolor (Chiroptera: Phyllostomidae): a new evidence. Chiroptera Neotropical, vol. 3, pp. 77-79.

BOZINOVIC, F., MUÑOZ, J.L.P. and CRUZ-NETO, A.P., 2007. Intraspecific variability in the basal metabolic rate: testing the food habits hypothesis. Physiological and Biochemical Zoology, vol. 80, no. 4, pp. 452-460. http://dx.doi.org/10.1086/518376. PMid: 17508340 .

DELORME, M. and THOMAS, D.W., 1999. Comparative analisys of the digestive efficiency and nitrogen and energy requirements of the phyllostomid fruit-bat (Artibeus jamaicensis) and the pteropodid fruit-bat (Rousettus aegyptiacus). Journal of Comparative Physiology. B, Biochemical, Systemic, and Environmental Physiology, vol. 169, no. 2, pp. 123-132. PMid:10227185.

DIERENFELD, E.S. and SEYJAGET, J., 2000. Intake and diet digestibility in three species of captive pteropodid bats. In: J. NIJBOER, J.M. HATT, W. KAUMANNS, A. BEIJNEN and W. GANSLOßER, eds. Zoo animal nutrition. Furth: Filander Verlag, pp. 73-89.

DUMONT, E.R., WEIBLEN, G.D. and WINKELMANN, J.R., 2004. Preferences of fig wasps and fruit bats for figs of functionally dioecious Ficus pungens. Journal of Tropical Ecology, vol. 20, pp. 1-6.

EMERY, P.W., 2012. Basic metabolismo: protein. Hertfordshire: Surgery- Oxford International Edition, vol. 30, pp. 209-213.

FLEMING, T.H., 1986. Opportunism versus specialization: the evolution of feeding strategies in frugivorous bats. In: A. ESTRADA and T.H. FLEMING, eds. Frugivores and seed dispersal. Dordrecht: W. Junk Publishers, pp. 105-118.

GARDNER, A.L., ed., 2008. Mammals of South America. Chicago: University of Chicago Press. Vol. 1.

GENUTH, S., 1998. For aggressive preventive management of type 2 Diabetes. What is the evidence and is it enough? The Journal of Family Practice, vol. 47, pp. 23-26.

GLEESON, M., 2005. Basic metabolismo I: Fat. Kidlington: The Medicine Publishing Company Ltd., vol. 3, pp. 83-88.

INSTITUTO ADOLFO LUTZ - IAL, 2005. Normas analiticas: métodos químicos e físicos de composição de alimentos. São Paulo: IAL. 60 p.
KOPPEN, W., 1948. Climatologia, con un estudio de los climas de la terra. México: Fondo de Cultura Económica.

LIMA, I.P. and REIS, N.R., 2004. The availability of Piperaceae and the search for this resource by Carollia perspicillata (Linnaeus) (Chiroptera, Phyllostomidae, Carollinae) in Parque Municipal Arthur Thomas, Londrina, Paraná, Brazil. Revista Brasileira de Zoologia, vol. 21, no. 2, pp. 371-377. http://dx.doi.org/10.1590/ S0101-81752004000200035.

MELLO, M.A.R., KALKO, E.K.V. and SILVA, W.R., 2008. Diet and abundance of the bat Sturnira lilium (Chiroptera) in a Brazilian Montane Atlantic Forest. Journal of Mammalogy, vol. 89, no. 2, pp. 485-492. http://dx.doi.org/10.1644/06-MAMM-A-411R.1.

MELLO, M.A.R., MARQUITTI, F.M.D., GUIMARÃES JUNIOR, J.R., KALKO, E.K., JORDANO, P. and AGUIAR, M.A., 2011. The missing part of seed dispersal networks: structure and robustness of bat-fruit interactions. PLoS One, vol. 6, no. 2, pp. e17395. http://dx.doi.org/10.1371/journal.pone.0017395. PMid:21386981.

MIKICH, S.B., 2002. A dieta dos morcegos fruglvoros (Mammalia, Chiroptera, Phyllostomidae) de um pequeno remanescente de Floresta Estacional Semidecidual do sul do Brasil. Revista Brasileira de Zoologia, vol. 19, no. 1, pp. 239-249. http://dx.doi. org/10.1590/S0101-81752002000100023.

MULLER, M.F. and REIS, N.R., 1992. Partição de recursos alimentares entre quatro espécies de morcegos frugívoros (Chiroptera, Phyllostomidae). Revista Brasileira de Zoologia, vol. 9, no. 3-4, pp. 345-355. http://dx.doi.org/10.1590/S010181751992000200022 .

MUYLAERT, R.L., MATOS, D.M.S. and MELLO, M.A.R., 2014. Interindividual variations in fruit preferences of the yellowshouldered bat Sturnira lilium (Chiroptera: Phyllostomidae) in a cafeteria experiment. Mammalia, vol. 78, no. 1, pp. 93-101. http://dx.doi.org/10.1515/mammalia-2012-0103.

NEUWEILER, G., 2000. Biology of bats. New York: Oxford University Press. 310 p.

ODUM, E.P., 2004. Fundamentos de ecologia. São Paulo: Fundação Calouste Gulbenkian. 820 p.

OLIVEIRA, A.M.R.; MARQUES, M.R. and FISHER, E.A., 2012. Determinação do teor nutricional de frutos da dieta de morcegos do Pantanal, Mato Grosso do Sul, Brasil. Visão Acadêmica., vol. 13, pp. 16-30.

PASSOS, F.C., SILVA, W.R., PEDRO, W.A. and BONIN, M.R., 2003. Frugivoria em morcegos (Mammalia, Chiroptera) no Parque Estadual Intervales, sudeste do Brasil. Revista Brasileira de Zoologia, vol. 20, pp. 511-517.

PASSOS, J.G. and PASSAMANI, M., 2003. Artibeus lituratus (Chiroptera, Phyllostomidae): biologia e dispersão de sementes no Parque do Museu de Biologia Prof. Mello Leitão, Santa Teresa (ES). Natureza online, vol. I, pp. 1-6.

PIANKA, E.R., 1982. Ecologia evolutiva. Barcelona: Omega. 365 p.

PINHEIRO, E.C., TADDEI, V.A., MIGLIORINI, R.H. and KETTELHUT, I.C., 2006. Effect of fasting on carbohydrate metabolism in frugivorous bats (Artibeus lituratus and Artibeus jamaicensis). Comparative biochemistry and physiology. Part B, Biochemistry \& molecular biology, vol. 143, no. 3, pp. 279-284. http://dx.doi.org/10.1016/j.cbpb.2005.11.013. PMid:16455278.

REIS, N.R., FREGONEZI, M.N., PERACCHI, A.L. and SHIBATTA, O.A., orgs. 2013. Morcegos do Brasil: guia de campo. Rio de Janeiro: Technical Books. 225 p. 
REIS, N.R., GALLO, P.H., PERACCHI, A.L., LIMA, I.P. and FREGONEZI, M.N., 2012. Sensitivity of populations of bats (Mammalia: Chiroptera) in relation to human development in northern Paraná, southern Brazil. Brazilian Journal of Biology = Revista Brasileira de Biologia, vol. 72, no. 3, pp. 511-518. http:// dx.doi.org/10.1590/S1519-69842012000300014. PMid:22990822.

REIS, N.R., MULLER, M.F., SOARES, E.S. and PERACCHI, A.L., 1993. Lista e chave de quirópteros do Parque Estadual Mata dos Godoy e arredores. Londrina. Pr. Semina: Ciências Biológicas e da Saúde, vol. 14, no. 2, pp. 120-126.

RICKLEFS, R.E., 2010. A economia da natureza. Rio de Janeiro: Guanabara Koogan. 570 p.

ROSSETTO, E.F.S. and VIEIRA, A.O.S., 2013. Vascular flora of the Mata dos Godoy State Park, Londrina, Paraná, Brazil. Check List, vol. 9, no. 5, pp. 1020-1034. http://dx.doi.org/10.15560/9.6.1020.

SALDAÑA-VÁZQUEZ, R.A. and SCHONDUBE, J.E., 2013. Food intake changes in relation to food quality in the Neotropical frugivorous bat Sturnira ludovici. Acta Chiropterologica, vol. 15, no. 1, pp. 69-75. http://dx.doi.org/10.3161/150811013X667867.

SANTOS, R.S., 2014. Relação entre massa corporal e dieta de quatro espécies de morcegos filostomídeos frugivoros (Chiroptera: Phyllostomidae) em fragmentos de Mata Atlântica no Sul do Brasil. Londrina: Universidade Estadual de Londrina, 62 p. Dissertação de Mestrado em Ciências Biológicas.

SAZIMA, I., 1976. Observations on the feeding habits of Phyllostomatid bats (Carollia, Anoura and Vampyrops) in Southeastern Brazil. Journal of Mammalogy, vol. 57, no. 2, pp. 381-382. http://dx.doi.org/10.2307/1379699.

SCHAEFER, H.M., SCHMIDT, V. and WINKLER, H., 2003. Testing the defence trade-off hypothesis: how contents of nutrients and secondary compounds affect fruit removal. Oikos, vol. 102, no. 2, pp. 318-328. http://dx.doi.org/10.1034/j.1600-0706.2003.11796.x.
SCHMIDT-NIELSEN, K., 2011. Fisiologia animal: adaptação e meio ambiente. São Paulo: Santos. 611 p.

SILVEIRA, M., 2006. A vegetação do Parque Estadual Mata dos Godoy. In: J.M.D. TOREZAN. Ecologia do Parque Estadual Mata dos Godoy. Londrina: Itedes, pp. 19-27.

SMITH, E.L., HILL, R.L., HANDLER, P. and WHITE, A., 1988. Bioquímica de mamíferos. Rio de Janeiro: Guanabara Koogan. 620 p.

STRAUBE, F.C. and BIANCONI, G.V., 2002. Sobre a grandeza e a unidade utilizada para estimar esforço de captura com utilização de redes-de-neblina. Chiroptera Neotropical, vol. 8, pp. 150-152.

VICENTE, R.F., 2006. O Parque Estadual Mata dos Godoy. In: J.M.D. TOREZAN. Ecologia do Parque Estadual Mata dos Godoy. Londrina: Itedes, pp. 13-18.

VIZOTTO, L.D. and TADDEI, V.A., 1973. Chave para determinação de quirópteros brasileiros. Revista Faculdade de Filosofia, Ciências e Letras de São José, vol. 1, pp. 1-73.

VLEUT, I., DE BOER, W.F., GALINDO-GONZÁLEZ, J. and VAZQUEZ, L.B., 2015. Niche differentiation and its relationship with food abundance and vegetation complexity in four frugivorous bat species in Southern Mexico. Biotropica, vol. 1, pp. 1-10.

VOIGT, C.C., SÖRGEL, K. and DECHMANN, D.K.N., 2010. Refueling while flying: Foraging bats combust food rapidly and directly to power flight. Ecology, vol. 91, no. 10, pp. 2908-2917. http://dx.doi.org/10.1890/09-2232.1. PMid:21058551.

WENDELN, M.C., RUNKLE, J.R. and KALKO, E.K.V., 2000. Nutritional values of 14 fig species and bat feeding preferences in Panama. Biotropica, vol. 32, no. 3, pp. 489-501. http://dx.doi. org/10.1111/j.1744-7429.2000.tb00495.x.

WHITE, R.C.T., 1993. The inadequate environment: nitrogen and the abundance of animals. New York: Springer. 